\title{
UGANDA
}

\section{EXTRACTS FROM THE RePORT OF THE Uganda National PARKS FOR THE YEAR I952, THE FIRST REPORT}

\section{By R. Dreschfield, Chairman of Trustees}

I think at this preliminary stage it would be appropriate if we set out the principles which will govern us in managing the National Parks on behalf of the public of the Protectorate. We, the Trustees, are not a tourist agency nor are we hotel keepers or a bus company. Our duty is to preserve the areas which have been set aside as National Parks as sanctuaries for wild life and as areas which in perpetuity can be preserved for the recreation primarily of the people of Uganda. The facilities which we may grant to tourists who wish to visit the Parks will be sccondary to our main function. It should, however, be borne in mind that while these facilities are secondary they are important, as the tourist industry provides directly some of the revenue necessary for running the Parks and also brings money into the country and so provides revenue for the Protectorate Government, thus assisting it in making grants towards the upkeep of the Parks.

The above remarks show how misconceived is the idea that the Parks take away land from the Africans. This is clearly the opposite to the truth. So long as these areas remain Parks they cannot be alienated and must remain as land set aside for the benefit of the population of the Protectorate. We have heard it said that this land has been taken away from the Africans because they will not be allowed freely to settle on it or to cultivate it. This again is a misconception because a people must have land over and above its immediate economic requirements. It must have space where individuals can go for holidays, where they can find a change from their everyday life and finally it must have a means whereby it can protect the natural beauties, both animal and vegetable, of its countryside; these beauties once lost can never be recovered.

The Uganda Parks are a priceless asset to the country and will fulfil all the above objects, in particular they will protect the wild life of the country, a heritage that cannot be valued in shillings and cents but must be preserved for the benefit of future generations who, owing to the fast development of the country, without the Parks may never have the opportunity of seeing it. 
By K. De P. Beaton, Director, Uganda National Parks

The Queen Elizabeth National Park.-A thorough reconnaissance was made of the portion of this Park lying to the north of the Kazinga Channel. It was decided that the best site on which to build the Safari Lodge was the Mweya Peninsula. This site is approached through interesting country and across a narrow neck of land commanding superb views. The Kazinga Channel with its wooded banks winds away to the east. To the north one looks across Katwe Bay to the foothills rising up to the peaks of the Ruwenzori Mountains, and to the west across Lake Edward to the blue hills of the Congo in the distance. Immediately below is a lightly wooded spit of land on which at most times of the day elephant, buffalo, hippo and other game can be seen grazing in the open. There is a wealth of bird life both terrestrial and aquatic on all sides. A more pleasant spot would be hard to find. The only drawback are lake flies and a few mosquitoes under certain conditions. The Lodges will have to be so constructed as to make them as insect-proof as possible by night.

The area of the craters lying between Chapman's road and the main road to the Congo will prove one of our biggest attractions. Here are probably more craters per square mile than in any other part of the world and each is different. Some hold emerald lakes, others grass, and yet others are densely wooded with euphorbias and indigenous trees. It is possible that some hold troops of chimpanzees, while elephant, buffalo, hippo, waterbuck, bushbuck, reedbuck, wart-hog and baboons were seen. Lions are also in this area, as their spoor was seen at a waterhole, and no doubt leopards and other game are there also. A circular track built along the rims between these craters, and threading its way through the whole area should prove a wonderful drive. From the high ground superb views are had over the lakes to the Ankole Hills and on a clear day even the craters of the Congo near Lake Kivu can be seen far to the south. High above and to the north the mountains rise steeply into the swirling mists which enshroud the summit, opening now and then to reveal the snow peaks and glaciers in all their beauty.

The Maramagamba Forest has not yet been explored, but the country lying to the south of the Forest to the Ishasha River, which demarcates the Congo border, was thoroughly explored. The whole of this portion of the Park is very pleasant park-like country with short grass and magnificent trees. It holds all the usual big game in numbers and many lions. It was here that a 
lioness was seen perched in a large tree some 40 feet above the ground. She had a grand view of the surrounding country. Here also are many kob, topi and waterbuck. A red forest duiker was seen and also three whale-billed storks. Bushbuck and wart-hog were very numerous. All the game was inclined to be wild, no doubt due to poaching and probably due also to the number of animals which I understand were shot to supply meat to the labour building the road. This area will need close control before it is too late.

\section{THE BEHAVIOUR OF SELADANG (Bibos gaurus)}

\section{By C. S. Ogilvie, Game Warden, Federation of Malaya}

Reaction to the Presence of Man and of Tiger.-Bull seladang grazing in the open seldom raise their heads from the serious business of filling their maws, but leave watch-dog duties to the cows. The latter seldom keep their heads down long, and it is on this account that care must be taken when stalking a herd up wind in the open. Some cow almost always has her head up looking about. I say " looking about", for they do not generally try the wind unless some strange or dangerous scent comes to them; then all, even the bulls, are on their toes. When an unfavourable wind is received they first throw up their heads and face into the wind, raising their noses ; after a good inspiration in this position, they swing their heads sharply first to one side, then after a short pause to the other side, testing the wind. They may repeat this action several times before being certain. From this they are able to determine the direction in which any danger may lie. If it is a scent denoting the presence of man they hesitate not on the order of going, stampeding away from the dreaded scent for perhaps seventy or a hundred yards. After their initial rush they pull up for a short pause making sure the danger is not on their tails. If the danger is not so close, they slip quietly away at a fast walk; if the source of danger is not following they keep this up, perhaps, for several miles, before they pull up for a real breather, but still remain very wary.

With tiger they respond very differently. To illustrate this I will recount an experience I had in the Krau game reserve before the Japanese invasion. One evening I was approaching an old "Jah Chong" 1 clearing which seladang used to frequent.

1 Local aboriginal tribe. 